\title{
Effect of Different Botanicals, Trichoderma viride and their Combinations against Alternaria solani causing Early Blight of Tomato
}

\author{
Indarapu Madhuri*, S. Mounika Reddy and Shashi Tiwari \\ Department of Plant Pathology, Naini Agricultural Institute, Sam Higginbottom University of \\ Agriculture, Technology And Sciences, Prayagraj, U.P, India \\ *Corresponding author
}

\section{A B S T R A C T}

\section{Keywords}

Tomato, Early blight, Alternaria solani, Trichoderma viride, Neem oil, Clove oil

Article Info

Accepted:

12 December 2020

Available Online:

10 January 2021
An experiment was carried out to evaluate the effect of different essential oils, bio-agent and their combinations in in vivo conditions for management of early blight of tomato caused by Alternaria solani and also to increase the growth parameters and yield. A total of eight treatments taken as seedling treatment namely Neem oil (5\%), Castor oil (5\%), Clove oil (5\%), Trichoderma viride $(5 \%)$, Neem oil $+T$. viride $(2.5 \%+2.5 \%)$, Castor oil + T. viride $(2.5 \%+2.5 \%)$ and lastly Clove oil $+T$. viride $(2.5 \%+2.5 \%)$ including control were replicated three times. During evaluation, all the seven treatments were found to be significantly superior over control in managing early blight and also in increasing the growth parameters and yield. Among all the treatments Neem oil $+T$. viride $(2.5 \%+2.5 \%)$ followed by Neem oil (5\%), Trichoderma viride (5\%) were significantly superior over other treatments in reducing early blight infection and also in increasing growth parameters of the crop. Subsequently, cost benefit ratio was also most desirable with Neem oil $+T$. viride $(2.5 \%+2.5 \%)$ followed by Clove oil $+T$. viride $(2.5 \%+2.5 \%)$. Trichoderma viride is most effective with the combination of essential oils than the single treatment to control early blight disease intensity and also in increasing the growth parameters respectively and also found to be economic.

\section{Introduction}

Tomato (Solanum lycopersicum L.) is one of the most widely grown vegetable crops in the world and it ranks 2 nd among vegetable crops in the world. It occupies first position in its nutrient contribution to human diet. In India, tomato is considered as "Protective food" due to its nutritive value. They are rich in source of micronutrients, lycopene, vitamin $\mathrm{C}, \beta$ carotene, potassium, folate, flavonoids, and vitamin E. It ranks 7th as source of vitamin ' $A$ ' and 10th as n' $C$ ' source among vegetables and it ranks 11th as vitamin ' $A$ ' source, 25th as vitamin ' $\mathrm{C}$ ' source among the fruits (Gopalan et al., 1995).Tomato is widely cultivated in 140 countries of the world with an annual production of $16826000 \mathrm{mt}$. Globally, tomatoes are grown in an area of 45.2 lakh hectares with a production of 12.4 million metric tonnes. India contribution to the world's production was 11.97 million 
tonnes. Tomato crop was grown in an area of 0.59 million hectare with a productivity of 19.97 tonnes per hectare. In an area of 7600 hectare with an annual production of 92500 tones Uttar Pradesh it occupied (Anonymus, 2016). The nutritive value of tomato per 100 gm of edible portion are as moisture 93.19 per cent, protein $1.90 \mathrm{gm}$, potassium $144 \mathrm{mg}$, copper $0.19 \mathrm{mg}$, sulphur $24 \mathrm{mg}$, chlorine $38.00 \mathrm{mg}$, vitamin C $31.00 \mathrm{mg}$, thiamine 0.07 $\mathrm{mg}$, riboflavin $0.01 \mathrm{mg}$. nicotinic acid 0.40 $\mathrm{mg}$, magnesium $15.00 \mathrm{mg}$, oxalic acid 2.00 $\mathrm{mg}$, phosphorous $36.00 \mathrm{mg}$, Iron 1.80 and vitamin A $320.00 \mathrm{mg}$. I.U. (Ankur Verma et.al, 2018).

Tomato is subjected to different fungal diseases like damping off, early blight, late blight, Fusarium wilt, leaf spots, powdery mildew, root rot and bacterial wilt etc. besides several other microbial diseases of bacteria, virus and nematodes. Tomato is susceptible to large number of diseases caused by various pathogens and caused a great concern in the production as well as in quality(Singh et al., 2004). Among the fungal diseases early blight also known as target spot disease incited by Alternaria solani (Ellis and Martin) Jones and Grout is one of the world's most catastrophic disease. The disease appears on leaves, stems, petioles, twig and fruits under favourable conditions resulting in defoliation, drying off of twigs and premature fruit drop and thus causing loss from 50 to 86 per cent in fruit yield (Mathur and Shekhawat, 1986). Alternaria solani is a soil inhabiting fungus and it can also come from other host through air and splashing rain. Leaf spots are scattered, brown with conspicuous, concentric rings surrounded by chlorotic halo. The stem lesions are usually restricted to one side of stem, sometimes concentric, elongated, and sunken. In the humid weather, the leaf spots coalesced, and enlarged. Fruit spots are dark brown, depressed, firm, and with distinct concentric rings(Mehrotra and Aneja, 2008).
In general, the control of tomato early blight disease has been exclusively based on the application of chemical pesticides. Several effective pesticides have been recommended against this pathogen, but they are not considered a long-term solution, due to concerns of expense, exposure risks and the hazards of its residues. Moreover, the development of resistance of pathogenic fungi towards synthetic pesticides is of great concern that can affect significantly the efficacy of chemical fungicides. Thus, to find safe efficacious and environmentally friendly fungicides considered as source of major concern (Mdee et al., 2009). The present study was aimed to determine the efficacies of different essential oils and Trichoderma viride against Early blight of tomato under Allahabad Agro climatic conditions as this disease causes enormous losses.

\section{Materials and Methods}

\section{Study site}

The present study was carried out in the department of plant pathology site located at central field of Sam Higginbottom university of Agriculture, Technology and Sciences, Prayagraj, Uttar Pradesh during 20192020.The soil of the experimental field was Sandy loam with $\mathrm{pH}$ 5.6. The experiment was laid out in a randomized complete block design with eight treatments including control and three replications each with a plot size of $2 \times 2 \mathrm{~m}$. The symptoms appeared after 60 days of transplanting.

\section{Isolation and identification of pathogen}

The infected leaf parts were cut into small pieces $(2-3 \mathrm{~mm})$, surface sterilization was done with $0.1 \%$ mercuric chloride solution for 30 seconds, washed 3 times in sterilized distilled water and then transferred aseptically on petri dishes and test tubes containing PDA. 
Inoculated Petri plates were incubated at $27 \pm 1^{\circ} \mathrm{C}$ for 5 to 7 days and examined at frequent intervals to see the growth. After a few days (3-4 days) the colony of the fungus appeared on the medium, the slide was prepared and identification of the pathogen was recorded by referring suitable literature and monographs (Ellis, 1976).The pathogen isolated from the Tomato leaves was identified as Alternaria solani causative agent of Early blight of tomato on the basis of symptoms and conidial characteristics.

Description of disease rating scale for early blight (Pandey et al., 2003)

\begin{tabular}{|c|c|}
\hline Rating & $\begin{array}{c}\text { Reaction } \\
\text { Description }\end{array}$ \\
\hline 0 & Free from infection \\
\hline 1 & $\begin{array}{l}\text { One or two necrotic spots on a few lower leaves of plants, } \\
\text { covering nearly } 1-10 \% \text { of the surface area of the plant }\end{array}$ \\
\hline 2 & $\begin{array}{l}\text { A few isolated spots on leaves, covering nearly } 11-25 \% \text { of the } \\
\text { surface area of the plant }\end{array}$ \\
\hline 3 & $\begin{array}{l}\text { Many spots coalesced on the leaves, covering } 26-50 \% \text { of the } \\
\text { surface area of the plant }\end{array}$ \\
\hline 4 & $\begin{array}{l}\text { Irregular, blighted leaves and sunken lesion with prominent } \\
\text { concentric rings on the stem petiole, fruit, covering } 51-75 \% \\
\text { leaf area of the plant. }\end{array}$ \\
\hline 5 & $\begin{array}{l}\text { Whole plants blighted, leaf and fruits starting to fall, } \\
\text { covering more than } 75 \% \text { leaf area ofplant. }\end{array}$ \\
\hline
\end{tabular}

Disease intensity

Percent Disease intensity (Chester, 1959 and Wheeler, 1969) was calculated by using the following formula:

Disease intensity $(\%)=\frac{\text { Sum of all disease ratings }}{\text { Total number of rating } \mathrm{x} \text { Maximum disease grade }} \times 100$

\section{Cost Benefit ratio:}

Benefit cost ratio is the ratio of net return to cost of cultivation, which can also be expressed as return per rupee invested. This index provides an estimate of the benefit a farmer derives from the expenditure he incurs in adopting a particular cropping system. Any value above 2.0 is considered safe as the farmer gets Rs. 2 for every rupee invested. The benefit cost ratio was calculated using the following formula
$\mathrm{CBR}=$ Net Return $(\mathrm{Rs} / \mathrm{ha}) /$ Total cost of cultivation (Rs/ha)

\section{Results and Discussion}

Effect of different essential oils and Trichoderma viride on plant growth parameters

Observations were recorded at 30,60 and 90 DAT. Growth parameters included plant height and branches. Of all the treatments, $\mathrm{T}_{5}$ (Neem oil + T.viride) showed the maximum growth in plant height and more number of branches followed by $\mathrm{T}_{4}$ ( Trichoderma viride) and $\mathrm{T}_{1}$ (Neem oil).

At 90 DAT maximum plant height was recorded in treatment $T_{5}$ - Neem oil + Trichoderma viride (77.65) followed by $\mathrm{T}_{4}$ Trichoderma viride (73.03), $\mathrm{T}_{1}$ - Neem oil (70.40), $\mathrm{T}_{7}-$ Clove oil + Trichoderma viride 
(56.09), $\mathrm{T}_{6}$ - castor oil + Trichoderma viride (55.34), $\mathrm{T}_{3}$ - clove oil (55.25), $\mathrm{T}_{2}$ - castor oil (54.91) are effective on plant height as compared to control. Least height was observed in control (41.09).

At 90 DAT maximum number of branches was recorded in $\mathrm{T}_{5}-$ Neem oil + Trichoderma viride (29.70) followed by $\mathrm{T}_{4}-$ Trichoderma viride (28.56), $\mathrm{T}_{1}-$ Neem oil (27.73), $\mathrm{T}_{7}-$ Clove oil + Trichoderma viride (24.93), $\mathrm{T}_{6}$ castor oil + Trichoderma viride (23.86), $\mathrm{T}_{3}$ clove oil (18.86), $\mathrm{T}_{2}$ - castor oil (17.13) are effective. Least number of branches was observed in control (15.06).

Similar findings were reported by Vats and Nandal (1993) and Jagdish Prasad et al., (2017). They evaluated the efficacy of biocontrol agents used (alone or in various combinations) against alternaria leaf spot and promoting plant growth. Maximum plant height observed in $T$. viride + Neem oil because inhibitory effect of bioagents due to hyper parasitism/ mycoparasitism, competition for space and nutritional source and antagonistic chemical produced by them and also the secondary metabolities such as alkaloids, phenoilcs and terponoids of neem oil that help in growth of the plant.

Effect of different essential oils and Trichoderma viride on Disease intensity (\%)

Observations were recorded at 60,75 and 90 DAT. Of all the treatments, $\mathrm{T}_{5}$ (Neem oil + T.viride) showed the minimum disease intensity followed by $\mathrm{T}_{1}$ (Neem oil) and $\mathrm{T}_{4}$ ( Trichoderma viride). At 90 DAT minimum disease intensity was observed in $\mathrm{T}_{5}$ - Neem oil + Trichoderma viride (33.19) followed by $\mathrm{T}_{1}$ - Neem oil (37.01), $\mathrm{T}_{4}$-Trichoderma viride (38.66), $\mathrm{T}_{7}-$ Clove oil + Trichoderma viride (44.45), $\mathrm{T}_{6}$ - Castor oil + Trichoderma viride (44.54), $\mathrm{T}_{3}$-Clove oil (45.87), $\mathrm{T}_{2}$ - Castor oil (48.28) and the maximum disease intensity was recorded in $\mathrm{T}_{0}$ - Control (57.13) and However, Neem oil + Trichoderma viride showed that significant decrease in disease intensity compared to all other treatments.

Table.1 Effect of treatments on plant height and number of branches

\begin{tabular}{|c|c|c|c|c|c|c|c|}
\hline & TREATMENTS & \multicolumn{2}{|c|}{\begin{tabular}{l|l} 
30 DAT & \\
\end{tabular}} & \multicolumn{2}{|c|}{\begin{tabular}{|c|c|} 
60 DAT & \\
\end{tabular}} & \multirow{2}{*}{$\begin{array}{l}\text { 90DAT } \\
\text { HEIGHT } \\
(\mathrm{cm})\end{array}$} & \multirow[b]{2}{*}{ BRANCHES } \\
\hline & & $\begin{array}{l}\text { HEIGHT } \\
(\mathrm{cm})\end{array}$ & BRANCHES & $\begin{array}{l}\text { HEIGHT } \\
(\mathrm{cm})\end{array}$ & BRANCHES & & \\
\hline $\mathbf{T}_{\mathbf{0}}$ & Control & 19.86 & 3.20 & 30.62 & 10.33 & 41.09 & 15.06 \\
\hline $\mathbf{T}_{1}$ & Neem oil & 28.88 & 5.30 & 47.08 & 13.03 & 70.40 & 27.73 \\
\hline $\mathbf{T}_{2}$ & Castor oil & 22.39 & 3.53 & 36.38 & 11.33 & 54.91 & 17.13 \\
\hline $\mathbf{T}_{3}$ & Clove oil & 25.04 & 3.60 & 39.57 & 11.40 & 55.25 & 18.86 \\
\hline $\mathbf{T}_{4}$ & Trichoderma viride & 29.54 & 5.36 & 48.16 & 13.06 & 73.03 & 28.56 \\
\hline $\mathbf{T}_{5}$ & $\begin{array}{l}\text { Neem oil } \\
\text { Trichoderma viride }\end{array}+$ & 29.58 & 5.93 & 48.87 & 14.33 & 77.65 & 29.70 \\
\hline $\mathbf{T}_{6}$ & $\begin{array}{l}\text { Castor } \quad \text { oil } \\
\text { Trichoderma viride }\end{array}+$ & 26.35 & 3.66 & 41.08 & 11.93 & 55.34 & 23.86 \\
\hline $\mathbf{T}_{7}$ & $\begin{array}{l}\text { Clove oil } \\
\text { Trichoderma viride }\end{array}+$ & 28.32 & 3.73 & 42.02 & 12.13 & 56.09 & 24.93 \\
\hline & F test & $\mathrm{S}$ & $\mathrm{S}$ & $\mathrm{S}$ & $\mathrm{S}$ & $\mathrm{S}$ & $\mathrm{S}$ \\
\hline & C.D. $(5 \%)$ & 1.33 & 0.32 & 1.52 & 0.75 & 1.67 & 0.52 \\
\hline & SEd $( \pm)$ & 0.61 & 0.15 & 0.70 & 0.34 & 0.77 & 0.24 \\
\hline
\end{tabular}


Table.2 Effect of treatments on early blight disease intensity of tomato

\begin{tabular}{|l|l|l|l|l|l|l|l|}
\hline & Treatments & $\mathbf{6 0}$ DAT & $\begin{array}{l}\text { \% } \\
\text { reduction } \\
\text { over } \\
\text { control }\end{array}$ & $\begin{array}{l}\mathbf{7 5} \\
\text { DAT }\end{array}$ & $\begin{array}{l}\text { \% } \\
\text { reduction } \\
\text { over } \\
\text { control }\end{array}$ & $\begin{array}{l}\mathbf{9 0} \\
\text { DAT }\end{array}$ & $\begin{array}{l}\text { \% } \\
\text { reduction } \\
\text { over } \\
\text { control }\end{array}$ \\
\hline $\mathbf{T}_{\mathbf{0}}$ & Control & 36.13 & - & 47.27 & - & 57.13 & - \\
\hline $\mathbf{T}_{\mathbf{1}}$ & Neem oil & 21.01 & 41.84 & 27.28 & 42.28 & 37.01 & 35.21 \\
\hline $\mathbf{T}_{\mathbf{2}}$ & Castor oil & 27.84 & 22.94 & 41.00 & 13.26 & 48.28 & 15.49 \\
\hline $\mathbf{T}_{\mathbf{3}}$ & Clove oil & 27.11 & 23.96 & 37.43 & 20.81 & 45.87 & 19.70 \\
\hline $\mathbf{T}_{\mathbf{4}}$ & Trichoderma viride & 21.84 & 39.55 & 27.59 & 41.63 & 38.63 & 32.38 \\
\hline $\mathbf{T}_{\mathbf{5}}$ & Neem oil + Trichoderma viride & 19.11 & 47.10 & 23.51 & 50.26 & 33.19 & 41.90 \\
\hline $\mathbf{T}_{\mathbf{6}}$ & Castor oil + Trichoderma viride & 26.67 & 26.18 & 34.73 & 26.52 & 44.54 & 22.03 \\
\hline $\mathbf{T}_{\mathbf{7}}$ & Clove oil + Trichoderma viride & 25.04 & 30.69 & 34.09 & 27.88 & 44.45 & 22.19 \\
\hline & F test & $\mathbf{S}$ & & $\mathrm{S}$ & & $\mathrm{S}$ & \\
\hline & C.D. $(\mathbf{5 \% )}$ & 0.89 & & 1.87 & & 1.88 & \\
\hline & SEd $\mathbf{(})$ & 0.41 & & 0.86 & & 0.87 & \\
\hline
\end{tabular}

Table.3 Effect of treatments on Yield and cost benefit ratio

\begin{tabular}{|l|l|l|l|l|l|}
\hline & Treatments & Yield (q/ha) & $\begin{array}{l}\text { Total input cost } \\
\text { Rs. }\end{array}$ & $\begin{array}{l}\text { Net income } \\
\text { Rs. /ha }\end{array}$ & C: B ratio \\
\hline $\mathbf{T}_{\mathbf{0}}$ & Control & 99.01 & $70,300 /-$ & $78,215 /-$ & $1: 1.11$ \\
\hline $\mathbf{T}_{\mathbf{1}}$ & Neem oil & 167.70 & $77,800 /-$ & $1,73,750 /-$ & $1: 2.23$ \\
\hline $\mathbf{T}_{\mathbf{2}}$ & Castor oil & 124.10 & $80,800 /-$ & $1,05,350 /-$ & $1: 1.30$ \\
\hline $\mathbf{T}_{\mathbf{3}}$ & Clove oil & 133.80 & $85,300 /-$ & $1,15,400 /-$ & $1: 1.35$ \\
\hline $\mathbf{T}_{\mathbf{4}}$ & Trichoderma viride & 164.52 & $70,580 /-$ & $1,76,200 /-$ & $1: 2.49$ \\
\hline $\mathbf{T}_{\mathbf{5}}$ & Neem oil + Trichoderma viride & 209.33 & $78,080 /-$ & $2,35,915 /-$ & $\mathbf{1 : 3 . 0 2}$ \\
\hline $\mathbf{T}_{\mathbf{6}}$ & Castoroil + Trichoderma viride & 145.33 & $81,080 /-$ & $1,36,915 /-$ & $1: 1.68$ \\
\hline $\mathbf{T}_{\mathbf{7}}$ & Clove oil + Trichoderma viride & 188.37 & $85,580 /-$ & $1,96,975 /-$ & $1: 2.30$ \\
\hline
\end{tabular}

Fig.1 Leaves showing early blight infection Fig.2 Fruit showing early blight infection

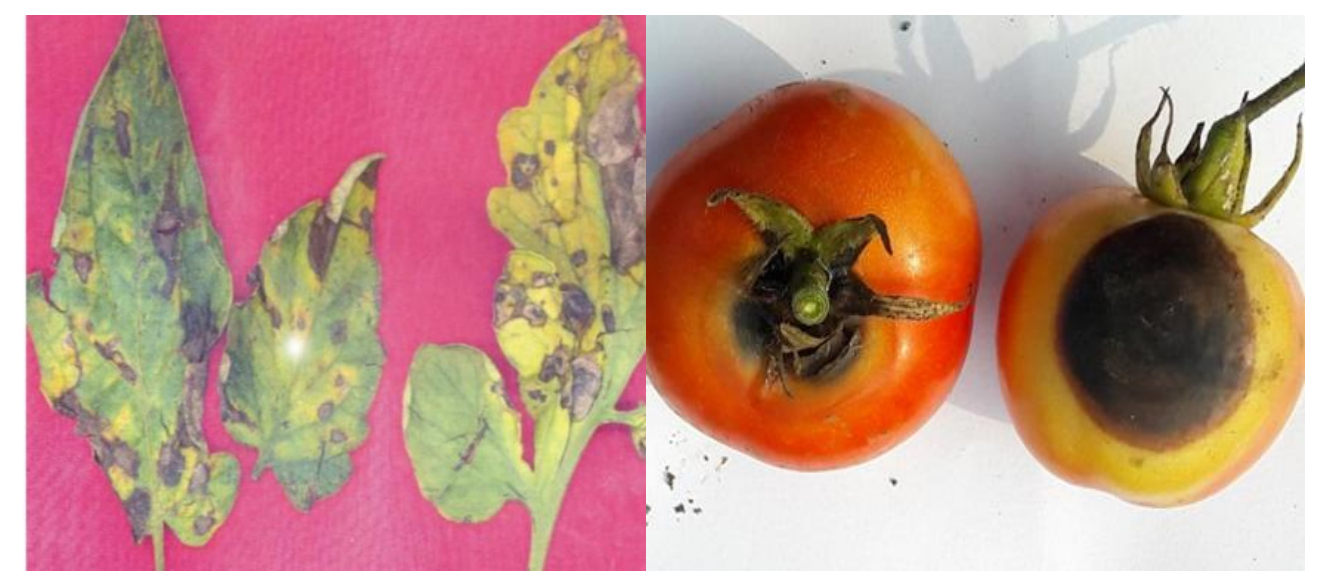


Fig.3 Effect of treatments on Plant growth

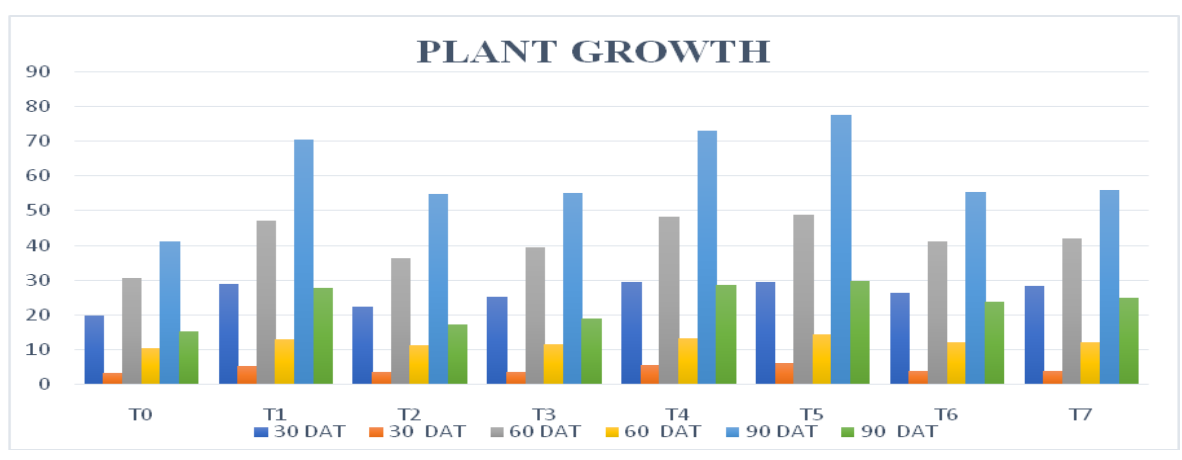

Fig.4 Effect of treatments on early blight disease intensity

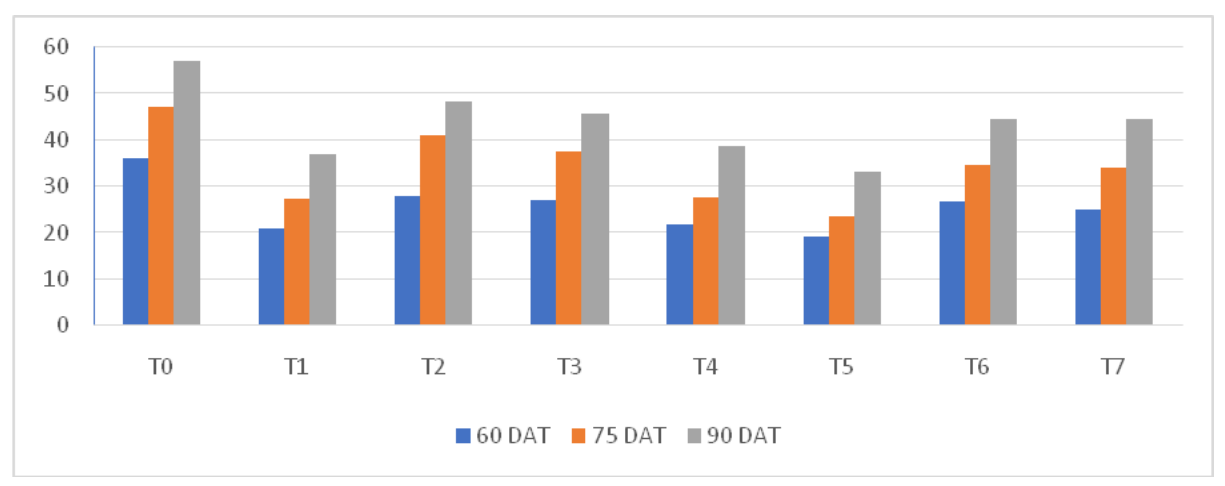

Fig.5 Effect of treatments on yield

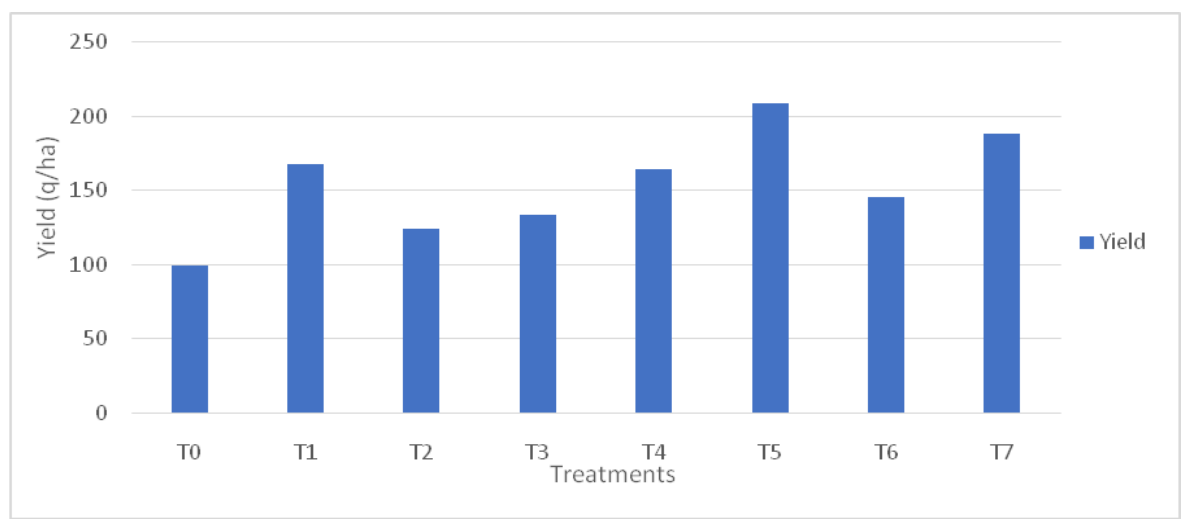

Similar findings were reported by Karthikeyan et al., (2008) and Patil et al., (2001). They evaluated the efficacy of Trichoderma viride alone and in combination with essential oils against early blight disease intensity of tomato in field condition. Minimum disease intensity was found in Trichoderma viride in combination with neem oil. The probable reason for such finding may be their inhibitory effects on disease development appeared due to production of antibiotic metabolities that inhibited disease development and also the secondary metabolities such as alkaloids, phenoilcs and terponoids of neem oil also inhibit the growth of the pathogen. 
Effect of different essential oils and Trichoderma viride on Yield and Cost Benefit ratio

The highest yield was recorded in $\mathrm{T}_{5}$ Neem oil $+T$. viride $(209.33 \mathrm{q} / \mathrm{ha})$ followed by $\mathrm{T}_{7}$ Clove oil $+T$. viride $(188.37 \mathrm{q} / \mathrm{ha}), \mathrm{T}_{1}$ Neem oil $(167.70 \mathrm{q} / \mathrm{ha}), \mathrm{T}_{4}$ Trichoderma viride (164.52 q/ha), $\mathrm{T}_{6}$ Castor oil + T. viride $(145.33$ $\mathrm{q} / \mathrm{ha}), \mathrm{T}_{3}$ Clove oil (133.80 q/ha) and the lowest was recorded in treatment $\mathrm{T}_{0}$ Control (99.01 q/ha). Likewise highest $\mathrm{B}: \mathrm{C}$ ratio shows in $\mathrm{T}_{5}$ Neem oil $+T$. viride $(1: 3.02)$ followed by $\mathrm{T}_{4}$ Trichoderma viride (1:2.49), $\mathrm{T}_{7}$ clove oil $+T$. viride $(1: 2.30), \mathrm{T}_{1}$ Neem oil (1:2.23), $\mathrm{T}_{6}$ Castor oil $+T$. viride $(1: 1.68), \mathrm{T}_{3}$ Clove oil(1:1.35), $\mathrm{T}_{2}$ Castor oil (1:1.30) and the lowest was recorded in treatment $\mathrm{T}_{0}$ Control $(1: 1.11)$

In conclusion since chemicals have many hazardous effects on the environment as well as on the person who handles it while application in the field and consumers using the product, using of essential oils and bio control agents in the field would be considered as it is beneficial and eco-friendly.

The present research concludes that that among all treatments, the treatment - Neem oil + Trichoderma viride proved to be best in inhibiting the effect of Alternaria solani. Subsequently, the same treatment had best effect in maximizing plant growth parameters and also yield as well. Thus, it can be finalized that Neem oil + Trichoderma viride is the most economical, eco-friendly way to control early blight of tomato. It also shows that botanicals with the combination of bioagent gives best effect than individual effect.

\section{References}

Anonymous., 2016. National Horticulture Board Indian Horticulture Database.

Ankur Verma, Surender Kumar, Harshita,
Ankita Shina and Shweta Jaiswal., (2018). Evaluate the efficacy of biocontrol agents and botanicals against early blight of potato caused by Alternaria solani. The Pharma Innovation Journal, 7(3): 28-30.

Ellis, M. B. (1976).More Dematiaceous Hyphomycetes. $\quad 1^{\text {st }}$ edition, Commonwealth Mycological Institute, Kew, Surrey, UK 507.

Gopalan, C., Ramashastri, B. V., \& Balasubramaniam, S. C. (1995). Nutritive value of Indian Foods. Ministry, Indian counsil of medical Research, Hyderabad, 61-65.

Jagdish Prasad Bugalia, Dr. Sunil Zacharia and Gopal Lal Kakraliya., (2017).Efficacy of Trichoderma spp. and garlic extract against Alternarial leaf blight of mustard (Brassica juncea L.). Journal of Pharmacognosy and Phytochemistry, 6(4): 796-798.

Karthikeyan, M., Radhika, K., Bhaskaran, R., Mathiyazhagan, S., Sandosskumar, R., Velazhahan, R., (2008). Biological control of onion leaf blight disease by bulb and foliar application of powder formulation of antagonist mixture. Archives of Phytopathology and Plant Protection, 6(41): 407-417.

Mathur, K. and Sekhawat, K.S. (1986).Chemical control of early blight in Kharif sown tomato. Indian J.Mycol. PL Pathol., 16:235-238.

Mdee, L. K., Masoko, P and Eloff, J.N. (2009). The activity of extracts of seven common invasive plant species on fungal phytopathogens. South African J. Bot., 75:375-379.

Mehrotra, R. S. and Aneja, K.R. (2008).An Introduction to Mycology, New age international(P) limited, Publishers, pp. 596.

Pandey, K.K., Pandey, P.K., Kallo, G. Banerjee, M.K, (2003). Resistance to early blight of tomato with respect to 
various parameters of disease epidemics. J. Gen. PlantPathol., 69: 364-371.

Patil, M.J., Ukey, S.P. and B.T. Raut, B.T., (2001). Evaluation of fungicides and botanicals for the management of early blight (Alternaria solani) of tomato. PKV-Research Journal, 25: 49-51.

Singh, Nempal, Bhardwaj, A.K., Kumar Abinash and Singh, K. M. (2004).Modem Technology on Vegetable Production. International Book Distribution Co.Lucknow., p 84-
98.

Vats, R. and Nandal, S.N., (1993). Optimization of dipping periods of tomato seedlings in plant extracts for the management of root-knot nematode, Meloidogyne javanica. Current Nematology, 4:161-164.

Wheeler, B. E. J., (1969).An introduction to plant disease. John Wiley Sons Limited London.

\section{How to cite this article:}

Indarapu Madhuri, S. Mounika Reddy and Shashi Tiwari. 2021. Effect of Different Botanicals, Trichoderma viride and their Combinations against Alternaria solani causing Early Blight of Tomato. Int.J.Curr.Microbiol.App.Sci. 10(01): 1011-1018. doi: https://doi.org/10.20546/ijcmas.2021.1001.122 